\title{
Conference Meeis on Dumping of Waste at Sea
}

THE inter-governmental conference on the dumping of waste at sea got under way in London this week with hopes high for its success. By the end of the ten-day meeting, a convention should have been signed prohibiting the dumping of certain wastes and limiting the dumping of others.

Mr Peter Walker, Secretary of State for the Environment, who opened the conference, said last week that he saw no reason why agreement should not be reached. There is, he said, no reason to delay this convention which, if it is agreed, will be the first tangible fruit of Stockholm. Mr Walker pointed out that Britain has already agreed a local convention on dumping in the North Sea and North Atlantic with other states that border those waters, and he hoped that a global convention would emerge from the current conference. Seventy-five countries are represented at the meeting, with eight more attending as observers along with representatives from eight United Nations agencies.

The idea is that a general convention will be drawn up, forbidding the disposal of certain wastes including organochlorines, heavy metals, persistent oil and tar wastes and bulky objects likely to endanger vessels. This global agreement will then be supplemented by a series of local agreements which will take into account local conditions. The Oslo Convention (as the North Sea agreement is known) is one example, and the Italians are already setting up a similar agreement to cover the western Mediterranean. In his opening speech, $\mathrm{Mr}$ Walker argued that once really toxic wastes have been eliminated from the seas, other wastes can be disposed of safely in varying quantities depending on the area. "For example we could safely dump in Liverpool Bay four or five times as much sewage sludge as goes there now ... on the condition that the sludge does not contain more dangerous contaminants than we can help."

$\mathrm{Mr}$ Walker also said that the approach to waste disposal must be a total one. "If we do not put waste into the sea, it has to go somewhere else. It would be silly to put it in a hole in the ground if that contaminated water supply". Nations therefore need to help each other with their waste disposal problems and share expertise in destroying noxious wastes.

Mr Walker made it equally plain that once a global ocean-dumping convention is agreed, the British Government is eager to see a convention on river pollution drawn up, and more work needs to be done on pollution from shipping.

The conference is a conference of officials rather than of ministers, with Britain's delegation including representatives from the Department of the Environment, the Ministry of Agriculture Fisheries and Food, the Foreign Office and the Department of Trade and Industry. Dr Martin Holdgate, head of the DOE's environmental pollution unit has been elected chairman of the conference.

One of the areas it is hoped the conference will cover is enforcement of the hoped-for convention. Mr Walker has made it plain that he hopes the convention will consist of more than pious promises and that methods of detection and enforcement will be agreed. Better methods for tracing culprits must be developed he said last week, and he referred to work on placing chemical tracing elements in tanker oil which would make it possible to trace dumped

\section{RESEARCH

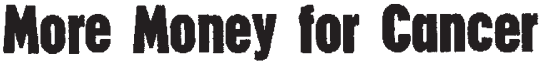

A SUDDEN increase in funds for cancer research could not be used effectively according to Lord Zuckerman in a report on cancer research prepared at the Prime Minister's request. But "a steady and substantial increase over the years would probably yield valuable results".

Lord Zuckerman's report was prepared following President Nixon's huge increase in funding cancer research in the United States. But Zuckerman concludes that attempting to compete with the resources available in the United States-which will spend about $\$ 440$ million in the fiscal year 1972-3-would be wasteful, but he does recommend that accommodation for research be improved and that major laboratories be given the assurance of long-term support so that a career structure in cancer research can be established. Further, defence establishments that are being run down-such as the Microbiological Research Establishment, Porton -should be turned over to cancer research and international cooperation should be strengthened.

Lord Zuckerman states that he is worried about the links between research and the clinicians which are not as close as they might be, with the result that, through ignorance, the latest treat- oil to the tanker that carried it.

$\mathrm{Mr}$ Walker also pointed out that the conference is only one step in solving the problems of keeping the oceans clean. The International Marine Consultative Organization's 1973 conference on shipping matters will be another step, and the UN conference on the Law of the Sea, which is also planned for next year, will also help. "We cannot attain perfection in one great leap," he said, "We have to make progress as and when we can and there will be many steps on the road".

For the British Government, the London conference is a minor diplomatic coup. $\mathrm{Mr}$ Walker and $\mathrm{Mr}$ Maguire made a mark at Stockholm by their protestations that they could not wait for the setting up of a United Nations agency to sign an anti-dumping convention. At the time, they seemed to ride rough-shod over the feelings of maritime nations--Brazil, for example -not invited to the preparatory conference at Reykjavik. ments are not always applied. He also believes that money spent helping the families of those dying of cancer would be money well spent.

The planning of new research, Lord Zuckerman says, should be governed by three considerations. First, it must be realized that the basic branches of biomedical research are interdependent; the development of any one branch at the expense of the others would result in a loss of efficiency. Second, money alone will not buy new ideas; the research must be of sufficiently high scientific standard to be of value. Third, scientific talent of the quality necessary to deal with the exceptionally difficult problems associated with cancer research is in short supply; full training programmes and the provision of career prospects are needed.

The reaction of the two chief cancer research organizations - the Imperial Cancer Research Fund and the Cancer Research Campaign-to the report is favourable. The two charities between them will spend $£ 6$ million of the $£ 10$ million spent on cancer research this year in Britain. Both described the report as "very sensible", but emphasized that while a sudden massive injection of money would only create a shortage of adequate research staff, the "steady and substantial increase" which Lord Zuckerman prescribes is still vitally important. 